\title{
KAJIAN KARAKTERISTIK TIPOLOGI PANTAI UNTUK PENGEMBANGAN WISATA REKREASI PANTAI DI SUKA ALAM PERAIRAN SELAT PANTAR KABUPATEN ALOR
}

\author{
Coastal Typological Characteristics Study for Recreational Tourism Development in Marine \\ Nature Strait Pantar Alor Regency \\ Oleh: \\ Imanuel Lamma Wabang ${ }^{1 *}$, Fredinan Yulianda ${ }^{2}$, dan Handoko Adisusanto ${ }^{2}$ \\ ${ }^{1}$ Mahasiswa Program Studi Pengelolaan Sumberdaya Pesisir dan Lautan \\ ${ }^{2}$ Staf Pengajar Program Studi Pengelolaan Sumberdaya Pesisir dan Lautan \\ "Korespondensi: wabangimanuel18@gmail.com
}

\begin{abstract}
ABSTRAK
SAP Selat Pantar terletak di Kabupaten Alor Provinsi Nusa Tenggara Timur. Kawasan ini memiliki daya tarik berupa pantai karang berpasir putih yang landai dengan pemandangan bawah laut yang indah. Penelitian ini dilaksanakan di SAP Selat Pantar Kabupaten Alor, pada bulan Agustus s/d Oktober 2016. Penelitian bertujuan untuk mengkaji kesesuaian kawasan untuk kegiatan wisata rekreasi pantai dan menganalisis daya dukung (carrying capacity) kawasan SAP Selat Pantar untuk kegiatan wisata bahari berbasis ekologi. Penelitian ini menggunakan data primer pengambilan data analisis kualitas air, metode penentuan kesesuaian kawasan berdasarkan perkalian skor dan bobot yang diperoleh dari setiap paremeter, kedalaman, tipe pantai, lebar pantai, kecerahan, kecepatan arus, material dasar perairan, pengamatan biota berbahaya, dan ketersediaan air tawar. Berdasarkan hasil penelitian menunjukan bahwa potensi ekowisata pantai di SAP Selat Pantar ditemukan ada dua kategori yaitu kategori sangat sesuai dengan nila IKW mencapai $85.71 \%$ dan kategori sesuai dengan nilai IKW sebesar 64.24\%. Daya dukung kawasan kategori ekowisata rekreasi pantai 302 (Orang/hari).
\end{abstract}

Kata kunci : ekowisata pantai, kesesuaian kawasan, daya dukung kawasan, SAP Selat Pantar.

\begin{abstract}
Pantar Strait SAP is located on Alor regency of East Nusa Tenggara province. This region has white sandy beaches sloping reef with beautiful underwater scenery. This research was conducted in Pantar Strait of Alor district, in August to October 2016. The study aimed to assess the suitability of the area for recreational beach tourism activities and marine ecology-based tourism activities and to analyze carrying capacity of the location. The ecology data were collected in this research. The method of determining the suitability of the area by multiplying scores and weights were obtained from each parameter, depth, type of beach, wide beach, brightness, speed current, soil, and dangerous biota and freshwater availability. The results of the study showed that the potential of ecotourism beach on Pantar Strait are two categories, was in very suitable with IKW members reached $85.71 \%$ and category suitable of $64.24 \%$ of IKW. The carrying capacity of coastal recreation area ecotourism was 322 (person /day).
\end{abstract}

Keywords : Ecotourism beach, conformity regions, carrying capacity,Selat Pantar. 


\section{PENDAHULUAN}

Ekowisata merupakan bentuk wisata yang menekankan tanggung jawab terhadap kelestarian alam, mempertahankan keutuhan budaya bagi masyarakat setempat dalam menikmati keindahan alam dengan cara tidak merusak sumberdaya alam sehingga keberadaannya tetap lestari (Tuwo 2011; Bjork 2000). The International Ecoturism Society (TIES) menyatakan bahwa ekowisata ini menyatukan antara aspek konservasi, masyarakat, dan wisata yang bertanggungjawab, serta menekankan adanya pembelajaran dan pendidikan. Dengan demikian ekowisata bahari dapat didefinisikan sebagai kegiatan wisata bertanggungjawab yang dilakukan di daerah pesisir dan laut yang mengutamakan kelestarian alam dan mendukung kesejahteraan masyarakat lokal.

Wilayah pesisir dan laut yang dapat dikembangkan menjadi kawasan wisata berupa pemandangan pantai yang indah dan keaslian lingkungan seperti kehidupan di bawah air. Pengembangan pantai sebagai tempat ekowisata merupakan jasa lingkungan dari alokasi sumberdaya yang cenderung akan memberikan manfaat pada kepuasan batin seseorang dikarenakan mengandung nilai estetika tertentu (Ali 2004).

Kabupaten Alor memiliki potensi wisata yang cukup besar untuk dikembangkan khususnya SAP Selat Pantar. Salah satunya pemanfaatan pesisir pantai untuk wisata. Daerah pantai dapat menjadi alternatif tujuan wisata bagi para wisatawan. WTO (2004) menyatakan bahwa hampir tiga per empat daerah destinasi wisata dunia adalah daerah pesisir

Suaka Alam Perairan Selat Pantar dan laut sekitarnya (SAP Selat Pantar) merupakan salah satu kawasan konservasi laut yang ditetapkan melalui Surat Keputusan Menteri Kelautan dan Perikanan Nomor 35/KEPMEN-KP/2015 tentang SAP Selat Pantar dan laut sekitarnya di Kabupaten Alor Provinsi Nusa Tenggara Timur. Keputusan menteri ini sebagai tindaklanjut dari Peraturan Bupati Nomor 06 Tahun 2009 tentang Pencadangan Kawasan Konservasi Laut Daerah Kabupaten Alor. SAP Selat Pantar memiliki zona pemanfaatan yang cukup besar dan memiliki potensi besar untuk pengembangan ekowisata bahari khususnya wisata pantai.

Keberadaan sumber daya alam yang dimiliki SAP Selat Pantar merupakan salah satu faktor pendorong dalam melakukan perjalanan wisata, baik wisatawan domestik maupun manca negara. Keberadaan sumber daya hayati sangat penting dalam pengembangan kegiatan ekowisata bahari. Maka dapat dipastikan bahwa kawasan pantai merupakan salah satu daerah tujuan wisata manca negara dan domestik karena memiliki keanekaragaman hayati yang tinggi, ditambah lagi dengan adanya warisan budaya yang beraneka ragam. Akan tetapi potensi wisata pantai tersebut sampai saat ini belum dioptimalkan dengan baik, terutama dari infrastruktur pendukungnya. Pernyataan tersebut membuktikan bahwa potensi wisata pantai di SAP Selat Pantar masih dapat dikembangkan lebih lanjut secara optimal. Belum dioptimalkannya sektor ini menjadi sebuah kerugian bagi pembangunan daerah, mengingat industri pariwisata merupakan salah satu potensi besar yang ada di Kabupaten Alor dan dapat memberikan kontribusi besar bagi pendapatan daerah tersebut dan bagi pertumbuhan daerah.

SAP Selat Pantar merupakan salah satu wilayah Kabupaten Alor yang terletak sekitar 20.5 km² dari Kota Kalabahi. SAP Selat Pantar juga memiliki potensi ekowisata pantai diantaranya, Pantai Sebanjar, Pantai Hula, Pantai Alaang, Pantai Jawa Toda dan Pantai Munaseli. Untuk pemanfaatan dan pengelolaan potensi ekowisata yanga ada di pantai SAP Selat Pantar tersebut maka perlu dilakukan sebuah penelitian terkait tentang Kajian Karakteristik Tipologi Pantai Untuk Pengembangan Wisata Rekreasi Pantai.

Tujuan penelitian ini adalah: 1) mengkaji kesesuaian kawasan untuk kegiatan wisata rekreasi pantai. 2) menganalisis daya dukung (carrying capacity) kawasan SAP Selat Pantar untuk kegiatan wisata rekreasi pantai. 


\section{METODE PENELITIAN}

Penelitian ini dilaksanakan di kawasan Pantai Suaka Alam Perairan (SAP) Selat Pantar Kabupaten Alor Provinsi Nusa Tenggara Timur pada bulan Agustus s/d Oktober 2016. Penentuan stasiun penelitian dilakukan dengan purpossive sampling. Jumlah stasiun penelitian sebanyak 5 titik dimana koordinat lokasinya ditentukan dengan menggunakan GPS.

Penelitian ini menggunakan data primer dan data sekunder. Data primer adalah data yang langsung diperoleh dari lapangan, mengukur kecerahan, tipe pantai, lebar pantai, material dasar perairan, kecepatan arus biota berbahaya, ketersedian air tawar. Dalam penelitian ini data juga diperoleh dari jawaban responden yang ada di obyek ekowisata Pantai SAP Selat Pantar Kabupaten Alor, terhadap wawancara pengisian kuesioner yang disampaikan langsung oleh peneliti. Sedankan data sekunder diperoleh dari Dinas Perikanan dan Kelautan Kabupaten Alor, Dinas Pariwisata dan Kebudayaan Kabupaten Alor, Jurnal, Tesis, Buku, Wisatawan, Kepala Desa, Tokoh Masyarakat, Nelayan, Badan Pusat Statistik (BPS). Sementara alat dan bahan yang digunakan selama penelitian dilihat pada Tabel 1.

Tabel 1 Alat dan bahan yang digunakan

\begin{tabular}{cll}
\hline No & Alat dan Bahan & Kegunaan \\
\hline 1 & GPS & Menentukan titik kordinat \\
2 & Roll Motor & Mengukur panjang pantai dan lebar pantai \\
3 & Kuisioner & Daftar pertanyaan \\
4 & Camera & Dokumentasi kegiatan \\
5 & Snorkling & Pengamatan biota berbahaya \\
6 & Current Meter & Untuk mengukur kecepatan arus \\
7 & Refraktometer & Mengukur salinitas \\
8 & Thermometer & Mengukur Suhu \\
9 & Seiche Disk & Mengukur kecerahan \\
10 & Sabak dan pensil & Alat tulis untuk mencatat \\
\hline
\end{tabular}

Analisa data yang digunakan dalam penelitian ini adalah analisis Indeks Kesesuaian Wisata (IKW). IKW kesesuaian wisata pantai mempertimbangkan 10 parameter penilaian meliputi tipe pantai, lebar pantai, kedalaman perairan, material dasar perairan, kecepatan arus, kemiringan pantai, kecerahan perairan, pasang surut, penutupan lahan pantai, biota berbahaya, dan kesediaan air tawar. (Yulianda et al. 2010).

Tabel 2 Kesesuaian wisata bahari kategori pantai

\begin{tabular}{|c|c|c|c|c|c|c|c|c|}
\hline No & Parameter & Bobot & $\begin{array}{c}\text { Kategori } \\
\text { S1 }\end{array}$ & Skor & $\begin{array}{c}\text { Kategori } \\
\text { S2 }\end{array}$ & Skor & $\begin{array}{c}\text { Kategori } \\
\text { S3 } \\
\end{array}$ & Skor \\
\hline 1 & $\begin{array}{l}\text { Kedalaman Perairan } \\
(\mathrm{m})\end{array}$ & 5 & $0-3$ & 3 & $>3-6$ & 2 & $>6-10$ & 1 \\
\hline 2 & Tipe Pantai & 5 & Pasir Putih & 3 & $\begin{array}{l}\text { Pasir Putih, } \\
\text { Sedikit Karang }\end{array}$ & 2 & $\begin{array}{l}\text { Pasir hitam, } \\
\text { berkarang, } \\
\text { sedikit terjal }\end{array}$ & 1 \\
\hline 3 & Lebar Pantai (m) & 5 & $>15$ & 3 & $<10-15$ & 2 & $3-<10$ & 1 \\
\hline 4 & $\begin{array}{l}\text { Material Dasar } \\
\text { Perairan }\end{array}$ & 3 & Pasir & 3 & $\begin{array}{l}\text { Karang } \\
\text { Berpasir }\end{array}$ & 2 & $\begin{array}{c}\text { Pasir } \\
\text { Berlumpur }\end{array}$ & 1 \\
\hline 5 & $\begin{array}{l}\text { Kecepatan Arus } \\
\text { (m/det) }\end{array}$ & 3 & $0-0,17$ & 3 & $0,17-0,34$ & 2 & $0,34-0,51$ & 1 \\
\hline 6 & Kemiringan Pantai $\left({ }^{0}\right)$ & 3 & $<10$ & 3 & $10-25$ & 2 & $>25-45$ & 1 \\
\hline
\end{tabular}




\begin{tabular}{|c|c|c|c|c|c|c|c|c|}
\hline 7 & $\begin{array}{l}\text { Kecerahan Perairan } \\
(\%)\end{array}$ & 1 & $>10$ & 3 & $>5-10$ & 2 & $3-5$ & 1 \\
\hline 8 & $\begin{array}{l}\text { Penutupan lahan } \\
\text { pantai }\end{array}$ & 1 & $\begin{array}{c}\text { Kelapa, } \\
\text { Lahan } \\
\text { Terbuka }\end{array}$ & 3 & $\begin{array}{c}\text { Semak } \\
\text { belukar, } \\
\text { rendah, savana }\end{array}$ & 2 & $\begin{array}{l}\text { Belukar } \\
\text { tinggi }\end{array}$ & 1 \\
\hline 9 & Biota Berbahaya & 1 & Tidak Ada & 3 & $\begin{array}{c}\text { Ubur-Ubur } \\
\text { dan Bulu Babi }\end{array}$ & 2 & $\begin{array}{c}\text { Bulu Babi, } \\
\text { Ikan Pari }\end{array}$ & 1 \\
\hline 10 & $\begin{array}{l}\text { Ketersediaan Air } \\
\text { Tawar (Jarak x km) }\end{array}$ & 1 & $<0,5$ & 3 & $>0,5-1$ & 2 & $>1-2$ & 1 \\
\hline
\end{tabular}

Sumber: modifikasi Yulianda et al. (2010)

Keterangan : Nilai Maksimum: 84

Indeks kesesuaian wisata (IKW) merupakan kelanjutan dari analisis matriks kesesuaian wisata pantai. Estimasi yang digunakan untuk kesesuaian wisata bahari (Yulianda et al. 2010) melalui persamaan dibawah ini:

$$
\mathrm{IKW}=\Sigma[\mathrm{Ni} / \mathrm{Nmaks}] \times 100 \%
$$

Dimana : IKW : Indeks Kesesuaian Wisata

$\mathrm{Ni} \quad$ : Nilai Parameter Ke-1 (bobot $\mathrm{x}$ skor)

Nmaks : Nilai maksimum dari suatu kategori wisata

Nilai Indeks Kesesuaian IKW adalah sebagai berikut :

Kategori S1 : Sangat Sesuai, dengan nilai IKW : $75-100 \%$

Kategori S2 : Sesuai, dengan nilai IKW : $50-<75 \%$

Kategori S3 : Tidak Sesuai, dengan nilai IKW : $<50 \%$

Selanjutnya, analisis daya dukung (carring capacity) ditujukan untuk pengembangan wisata bahari dengan memanfaatkan potensi kawasan sumber daya pesisir, pantai dan pulau-pulau kecil. Menurut Yulianda et al. (2010) konsep daya dukung ekowisata mempertimbangkan dua hal, yakni (1) kemampuan alam untuk mentolerir gangguan atau tekanan dan manusia, dan (2) standar keahlian sumber daya alam.

Metode yang dipakai dalam menghitung daya dukung untuk pengembangan ekowisata bahari dengan menggunakan konsep daya dukung kawasan (DDK). Daya dukung kawasan (DDK) adalah jumlah maksimum pengunjung yang secara fisik dapat ditampung dikawasan yang disediakan pada waktu tertentu tanpa menimbulkan gangguan pada alam dan manusia. Secara matematis dapat diformulasikan sebagai berikut (Yulianda et al. 2010).

$$
\mathrm{DDK}=\mathrm{K} x \mathrm{Lp} / \mathrm{LtxWt} / \mathrm{Wp}
$$

Dimana : DDK : Daya dukung kawasan (orang/hari)

$\mathrm{K} \quad$ : Potensi ekologis pengunjung per satuan unit area

Lp : : Luas area atau panjang area yang dapat di manfaatkan

Lt : Unit area untuk kategori tertentu

Wt : Waktu disediakan oleh kawasan untuk kegiatan wisata

$\mathrm{Wp} \quad$ : Waktu yang dihabiskan oleh pengunjung untuk setiap kegiatan

Potensi ekologis pengunjung ditentukan oleh kondisi sumberdaya dan jenis kegiatan yang akan dikembangkan. Luas suatu area yang dapat digunakan oleh pengunjung harus memper-timbangkan kemampuan alam untuk mentolerir pengunjung sehingga keaslian tetap terjaga, seperti yang ditunjukan pada Tabel 3. 
Tabel 3 Potensi ekologis pengunjung (K) dan luas area kegiatan (Lt) dan Prediksi waktu yang dibutukan untuk setiap kegiatan wisata bahari

\begin{tabular}{ccc}
\hline Jenis Kegiatan & $\mathrm{K}$ & $\mathrm{Lt}$ \\
& $\Sigma(\mathrm{org})$ & Unit Area \\
\hline Wisata Pantai & 1 & $50 \mathrm{~m}$ \\
Jenis Kegiatan & Waktu yang di butuhkan & Total Waktu 1 hari \\
& WP (Jam) & Wt (Jam) \\
Wisata Pantai & 3 & 6 \\
\hline
\end{tabular}

Sumber: Yulianda et al. 2010

Keterangan:

Wisata pantai: 1 orang setiap 50m panjang pantai

\section{HASIL DAN PEMBAHASAN}

\section{Gambaran Umum SAP Selat Pantar}

SAP Selat Pantar terletak di Kabupaten Alor, secara astronomis terletak pada 8005'01"-8034'11" LS dan 123044'35"-124039'30" BT. Batas wilayah administratif SAP Selat Pantar yaitu berbatasan dengan Batas Utara berbatasan dengan Laut Flores, Batas Selatan berbatasan dengan Selat Ombay, Batas Barat berbatasan dengan Selat Alor dan Kabupaten Lembata, Batas Timur berbatasan dengan Selat Wetar dan perairan Republik Demokraktik Timor Leste.

SAP Selat Pantar memiliki ekosistem perairan yang menarik dengan keanekaragaman hayaiti yang tinggi. Pada musim tertentu, perairan Selat Pantar merupakan jalur migrasi paus yang merupakan daya tarik kawasan. Karena keunikan tersebut, maka kawasan Selat Pantar dan sekitarnya telah ditetapkan sebagai Taman Laut melalui Surat Keputusan Bupati Nomor 5 Tahun 2002. Taman Laut Selat Pantar mempunyai fungsi utama sebagai perlindungan sisitem penyangga kehidupan, pengawetan, keaneragaman jenis flora dan fauna serta pemanfaatan untuk penelitian, pendidikan, budidaya dan wisata terutama wisata bahari. Selain fungsi tersebut, kawasan perairan Taman Laut Selat Pantar dideklarasikan menjadi salah satu daerah KawasanKonservasiLaut Daerah (KKLD). Dikarenakan adanya perluasan kawasan konservasi, maka pada tanggal 6 Maret 2009 dikeluarkan peraturan Bupati Alor Nomor 6 Tahun 2009 yang mengubah Perbup Alor Nomor 12 Tahun 2006. Pencadangan Kawasan Konservasi Laut Daerah (KKLD) Kabupaten Alor adalah momentum dari Pemerintah Kabupaten Alor sebagai langkah awal untuk pengelolaan perairan laut dan pesisir yang lebih baik dan lebih mensejahterahkan masyarakat pesisir Kabupaten Alor. Tindak lanjut dari pencadangan SAP Daerah tersebut maka pada tanggal 16 Juni 2015 telah ditetapkan melalui SK Menteri Kelautan dan Perikanan Nomor 35/KEPMEN-KP/2015 Tentang SAP Selat Pantar dan Laut Sekitarnya di Kabupaten Alor Propinsi Nusa Tenggara Timur dengan status sebagai Suaka Alam Perairan Selat Pantar.

\section{Kondisi Lingkungan Perairan Pantai KKP Selat Pantar}

Kualitas perairan merupakan parameter yang dipertimbangkan dalam pengembangan kegiatan wisata bahari. Dalam menentukan tingkat kesesuaian wisata wisata pantai. parameter kualitas perairan yang dipertimbangkan adalah kedalaman perairan, kecepatan arus, ketersediaan air tawar.

Pengukuran parameter fisik lingkungan perairan kesesuaian kawasan wisata pantai kategori rekreasi pantai mengacu pada matriks kesesuaian menurut Yulianda (2007) yang terdiri dari 10 parameter sebagaimana terlihat dalam Tabel 4. 
Tabel 4. Hasil pengukuran parameter kesesuaian kawasan wisata pantai

\begin{tabular}{|c|c|c|c|c|c|c|c|c|c|c|}
\hline \multirow{2}{*}{ NO } & \multirow{2}{*}{ PARAMETER } & \multicolumn{9}{|c|}{ STASIUN PENELITIAN } \\
\hline & & 1 & 2 & 3 & 4 & 5 & 6 & 7 & 8 & 9 \\
\hline 1 & $\begin{array}{l}\text { Kedalaman } \\
\text { Perairan(m) }\end{array}$ & 1.8 & 2,3 & 1,7 & 2.6 & 1.7 & 3,2 & 1,4 & 1.7 & 1.1 \\
\hline 2 & Tipe Pantai & Pasir & Karang & Pasir & Karang & Pasir & Karang & Pasir & Karang & Pasir \\
\hline 3 & $\begin{array}{l}\text { Lebar Pantai } \\
\text { (m) }\end{array}$ & 20,41 & 16,34 & 25,5 & 12,50 & 20,41 & 16,34 & 27,5 & 12,50 & 27,15 \\
\hline 4 & $\begin{array}{l}\text { Material Dasar } \\
\text { Perairan }\end{array}$ & Pasir & Karang & Pasir & Karang & Pasir & Karang & Pasir & Karang & Pasir \\
\hline 5 & $\begin{array}{l}\text { Kecepatan Arus } \\
\text { (m.d) }\end{array}$ & 0,5 & 0,8 & 0,3 & 0,1 & 0,4 & 0,2 & 0,5 & 0.8 & 0,9 \\
\hline 6 & $\begin{array}{l}\text { Kemiringan } \\
\text { Pantai }\end{array}$ & 8.9 & 11,2 & 9.1 & 11,6 & 7,2 & 16,7 & 4,3 & 5,2 & 3,1 \\
\hline 7 & $\begin{array}{c}\text { Kecerahan } \\
\text { Perairan (\%) }\end{array}$ & 100 & 100 & 100 & 100 & 100 & 100 & 100 & 100 & 100 \\
\hline 8 & $\begin{array}{l}\text { Penutupan } \\
\text { Lahan Pantai }\end{array}$ & $\begin{array}{c}\text { Lahan } \\
\text { Terbuka }\end{array}$ & $\begin{array}{c}\text { Lahan } \\
\text { Terbuka }\end{array}$ & $\begin{array}{c}\text { Lahan } \\
\text { Terbuka }\end{array}$ & $\begin{array}{c}\text { Lahan } \\
\text { Terbuka }\end{array}$ & $\begin{array}{c}\text { Lahan } \\
\text { Terbuka }\end{array}$ & $\begin{array}{c}\text { Lahan } \\
\text { Terbuka }\end{array}$ & $\begin{array}{c}\text { Lahan } \\
\text { Terbuka }\end{array}$ & $\begin{array}{c}\text { Lahan } \\
\text { Terbuka }\end{array}$ & $\begin{array}{c}\text { Lahan } \\
\text { Terbuka }\end{array}$ \\
\hline 9 & $\begin{array}{c}\text { Biota } \\
\text { Berbahaya }\end{array}$ & $\begin{array}{c}\text { Tidak } \\
\text { ada }\end{array}$ & $\begin{array}{l}\text { Tidak } \\
\text { ada }\end{array}$ & $\begin{array}{c}\text { Tidak } \\
\text { ada }\end{array}$ & $\begin{array}{l}\text { Tidak } \\
\text { ada }\end{array}$ & $\begin{array}{l}\text { Tidak } \\
\text { ada }\end{array}$ & $\begin{array}{l}\text { Tidak } \\
\text { ada }\end{array}$ & $\begin{array}{l}\text { Tidak } \\
\text { ada }\end{array}$ & $\begin{array}{l}\text { Tidak } \\
\text { ada }\end{array}$ & $\begin{array}{l}\text { Tidak } \\
\text { ada }\end{array}$ \\
\hline 10 & $\begin{array}{c}\text { Ketersediaan } \\
\text { air tawar }\end{array}$ & 0.04 & 0.05 & 0.07 & 0.05 & 0.06 & 0.05 & 0.05 & 0.09 & 0.09 \\
\hline
\end{tabular}

Sumber: Hasil olahan 2016

\section{Analisis kesesuaian ekowisata pantai kategori rekreasi}

1. Kedalaman Perairan

Kedalaman perairan adalahsalah satu parameter fisik perairan cukup penting yang diperhitungkan dalam penentuan suatu kawasan untuk dijadikan sebagai kawasan wisata pantai khususnya mandi dan renang karena sangat berpengaruh pada aspek keselamatan pada saat berenang. Secara fisik kedalaman perairan yang dangkal cukup baik untuk dijadikan sebagai objek rekreasi mandi dan renang.

Hasil pengukuran kedalaman perairan SAP Selat Pantar menunjukan bahwa kisaran kedalaman perairan pantai mencapai 1,1 m -2,6 m. Hal ini berarti Selat Pantar termasuk dalam kategori sangat sesuai dan sesuai untuk kegiatan pengembangan wisata pantai. Hal ini didukung dengan pernyataan (Hazeri 2014) yang memberikan batasan nilai kedalaman untuk kesesuaian kedalaman untuk ekowisata pantai kategori cukup sesuai antara 3 hingga 6 meter.

2. Tipe Pantai

Berdasarkan hasil pengamatan di lokasi penelitian menunjukan bahwa tipe pantai di Selat Pantar adalah tipe pantai berpasir putih, dan tipe pasir dengan sedikit berkarang. sehingga hal ini merupakan salah satu keunikan yang dimiliki pantai di Selat Pantar karena memberikan kesan tersendiri bagi pegunjung yang datang ke pantai terutama bagi pengunjung yang ingin melakukan rekreasi Pantai. Hal ini sesuai dengan pendapat Yulianda (2007) bahwa untuk wisata pantai akan sangat baik jika suatu pantai merupakan pantai yang berpasir atau dengan kata lain didominasi oleh substrat pasir, dibandingkan dengan pantai yang berbatu atau pantai yang didominasi oleh substrat karang dapat mengganggu kenyamanan wisatawan.

Hasil pengamatan secara visual di lapangan pada setiap stasiun dapat dilihat pada (Tabel 4). Bahwa pasir di sepanjang Pantai SAP Selat Pantar merupakan pasir putih dan pasir campur berkarang. Pasir berkarang yang ada di Pantai SAP Selat Pantar memberikan kesan tersendiri bagi pegunjung yang datang ke Pantai tersebut terutama bagi pengunjung yang ingin melakukan rekreasi Pantai. 
Karang yang ada di Pantai SAP Selat Pantar didominasi dengan bentuk sesuai dengan merayap sesuai gelombang yang besar. Secara visual menurut Pangesti (2007) dalam (Hazeri 2014) jenis dan warna pasir pada suatu objek ekowisata memberikan nilai tersendiri bagi estetika pantai itu sendiri dimana pantai yang memiliki jenis pasir putih dan pasir hitam yang berukuran sedang sampai kasar sangat diminati oleh para wisatawan. Hal ini juga diperkuat dengan Widiatmaka (2007) dalam Armos (2013) bahwa tipe pantai yang sangat sesuai untuk kegiatan wisata pantai berdasarkan jenis substrat/sedimen adalah pantai berpasir.

\section{Lebar Pantai}

Berdasarkan hasil pengukuran lebar pantai menunjukan bahwa lebar pantai selat pantar berkisar 12,50-27,15 m. hal ini berarti lebar pantai yang dimiliki Pantai Selat Pantar termasuk dalam kategori sesuai dan sangat sesuai karena telah melebihi dari batas yang telah ditentukan sebagai suatu tempat wisata pantai. Selain itu pantai di Selat Pantar memiliki tipe pantai yang landai. Menurut bentuknya pantai dapat dibedakan menjadi empat macam yaitu pantai datar, landai, curam dan pantai terjal (Yulianda 2007).

Menurut Rahmawati (2009) bahwa lebar pantai berkaitan dengan luasnya lahan pantai yang dapat dimanfaatkan untuk berbagai aktivitas wisata pantai. Lebar pantai yang sangat sesuai untuk wisata pantai adalah lebih dari 15 meter, sedangkan lebar pantai kurang dari 3 meter dianggap tidak sesuai untuk wisata pantai. Lebar pantai sangat mempengaruhi aktivitas yang dilakukan para wisatawan, semakin lebar suatu pantai maka semakin baik untuk wisatawan dalam melakukan aktivitasnya, namun semakin kecil lebar pantai yang dimiliki oleh suatu tempat wisata maka pengunjung merasa tidak nyaman untuk melakukan aktivitas.

\section{Material Dasar Perairan}

Material Dasar Perairan/ Substrat merupakan penentu kecerahan suatu perairan.Pengamatan Material Dasar Perairan dilakukan dengan cara melakukan pengamatan secara langsung di lokasi penelitian melihat secara visual pada 7 stasiun penelitian. Berdasarkan hasil pengamatan dilapangan dapat dilihat pada Tabel 4. Material dasar perairan di Pantai SAP Pantaryakni jenispantai berpasir putih dan pasir bercampur sedikit karang. Hasil penelitian ini juga didukung oleh pendapat Yulianda (2007) bahwa material dasar perairan yang berwarna putih sangat sesuai untuk menunjang ekowisata di pantai SAP Selat Pantar

\section{Kecepatan Arus}

Menurut Sudarto (1993) terdapat beberapa jenis arus yang umum dikenal adalah arus pasang surut, arus akibat gelombang (arus sejajar pantai), arus akibat tiupan angin, dan arus yang disebabkan perbedaan densitas air laut. Pengukuran arus yang dilakukan selama berada dilokasi penelitian yaitu arus yang dipengaruhi oleh gelombang.Pengambilan data kecepatan arus dilakukan terlebih dahulu menentukan titik koordinat pada 7 stasiun penelitian yang telah ditentukan dengan menggunakan GPS.

Hasil pengukurun kecepatan arus di SAP Selat Pantar berada pada kisaran 0.1-0.9 m/s. Kondisi ini termasuk dalam kategori S1 (sangat sesuai) dalam indeks kesesuaian untuk wisata rekreasi pantai (Yulianda et al. 2010). Kecepatan arus di Pantai SAP Selat Pantar dapat dilihat pada Tabel 4. Kecepatan arus erat kaitannya dengan kenyamanan wisatawan yang datang ke objek wisata tersebut jika arus dalam keadaan kencang sebaiknya pengunjung tidak melakukan aktivitas ekowisata karena akan berbahaya untuk keselamatan pengunjung yang datang, jika kecepatan arus relative tenang akan memberikan kesan kenyamanan bagi wisatawan yang ingin melakukan aktivitas ekowisata.

\section{Kecerahan}

Menurut Effendi (2003) menyatakan bahwa nilai kecerahan sangat dipengaruhi oleh padatan tersuspensi dan kekeruhan, keadaan cuaca, waktu pengukuran, serta ketelitian orang yang melakukan pengukuran. Kecerahan perairan dalam kaitannya dengan kegiatan ekowisata pantai sangat berperan 
dalam hal kenyamanan para wisatawan pada saat berenang. Pengukuran kecerahan di lokasi penelitian dilakukan dengan cara menggunakan secchi disk yang diikat dengan tali kemudian diturunkan perlahan-lahan ke dalam perairan pada lokasi pengamatan sampai pada batas visual secchi disk tersebut tidak dapat terlihat lalumengukur panjang tali danmencatat posisi pengambilan data. Hasil pengukuran kecerahan Pantai SAP Selat Pantar dapat dilihat pada Tabel 4.

Hasil pengukuran parameter kecerahan perairan menunjukkan bahwa perairan pantai Selat Pantar memiliki nilai kecerahan yang sangat sesuai untuk kategori rekreasi yakni mencapai $100 \%$. Hasil penelitian ini juga sama dengan DKP Kab. Alor (2013) yang melakukan penelitian di sekitar kawasan KKP Selat Pantar diperoleh nilai kecerahan di perairan Selat Pantar mencapai $100 \%$. Begitu juga hal nya di Pantai SAP Selat Pantar yang diamati langsung oleh peneliti bahwa dasar Perairan masih tampak dilihat dengan jelas sampai dasar perairan.

\section{Pengamatan Biota Berbahaya}

Pengamatan biota berbahaya perlu dilakukan untuk mengetahui ada atau tidaknya biota berbahaya yang akan mengangu pengunjung wisata. Adapun biota berbahaya bagi pengunjung wisata diantaranya gastropoda, karang api, landak laut, bulu babi, ubur-ubur, anemon dan ular laut. Pengamatan biota berbahaya dilakukan berdasarkan snorkeling pada 7 stasiun penelitian dan menggali informasi secara mendalam kepada para pengunjung, masyarakat sekitar dan pihak pengelola menunjukan bahwa biota berbahaya tidak ditemukan di kawasan Pantai SAP Selat Pantar sehingga kawasan ini aman untuk menunjang aktifitas kegiatan wisata pantai.

\section{Penutupan Lahan Pantai}

Penutupan lahan dalam matriks kesesuaian wisata kategori rekreasi terbagi menjadi lahan terbuka dan kelapa, semak belukar rendah dan semak belukar tinggi, pemukiman dan pelabuhan. Dari hasil pengamatan dilapangan menunjukan bahwa penutupan lahan di Pantai SAP Selat Pantar adalah lahan terbuka (Tabel 4). Jenis tutupan lahan yang terbuka sangat sesuai untuk kegiatan wisata pantai.

\section{Ketersediaan Air Tawar}

Pantai di perairan Selat Pantar dapat dikatakan sangat sesuai untuk aktivitas wisata pantai, karena memiliki ketersediaan air tawar sebesar 0,5 -0,9 km. Menurut pendapat Dahuri, 2003 bahwa sumber air tawar mutlak diperlukan, terutama untuk kelangsungan hidup penduduk dan menunjang pengembangan potensi kepariwisataan diwilayah pulau-pulau kecil. Maka apabila dihubungkan dengan kegiatan wisata pantai maka hal ini erat kaitannya karena sebagai penunjang bagi wisatawan dalam melakukan kegiatan aktifitas wisata. Sebagaimana menurut Yulianda (2007) pada matriks kesesuaian lahan kategori wisata pantai bahwa suatu wisata pantai dapat dikatakan sangat sesuai jika memiliki jarak ketersediaan air tawar $<0,5 \mathrm{~km}$. Selain itu menurut (Handayani 2010) Saat melakukan Kegiatan wisata, ketersediaan air bersih berupa air tawar sangat diperlukan untuk menunjang fasilitas pengelolaan maupun pelayanan wisata. Hal ini juga merupakan menjadi kriteria penilaian terhadap kelayakan prioritas pengembangan wisata pantai.

\section{Analisis kesesuaian kawasan ekowisata rekreasi pantai}

Berdasarkan hasil analisis indeks kesesuaian kawasan wisata (IKW) yang telah diperoleh pada 5 stasiun penelitian. Peneliti menganalisis kesesuaian berdasarkan aspek penilaian yang disesuaikan dalam tabel paremeter kesesuain ekowisata pantai rekreasi, menghitung analisis kesesuaian kawasan berdasarkan (Yulianda 2007). Secara keseluruhan data hasil perhitungan Indeks Kesesuaian Wisata, kesesuaian wisata bahari kategori wisata pantai ditampilkan pada Tabel 5 dan Gambar 1. 
Tabel 5 Hasil analisis kesesuaian kawasan pantai kategori rekreasi.

\begin{tabular}{cccccc}
\hline Stasiun & Lokasi & Jumlah Skor & $\begin{array}{c}\text { Nilai } \\
\text { Maksimum }\end{array}$ & IKW (\%) & Kategori \\
\hline 1 & Sebanjar & 72 & 84 & 85.71 & Sangat Sesuai \\
2 & Hula & 54 & 84 & 64.24 & Sesuai \\
3 & Alaang & 72 & 84 & 85.71 & Sangat Sesuai \\
4 & Jawa Toda & 62 & 84 & 73.80 & Sesuai \\
5 & Munaseli & 75 & 84 & 89.28 & Sangat Sesuai \\
\hline
\end{tabular}

Sumber: Hasil olahan 2016

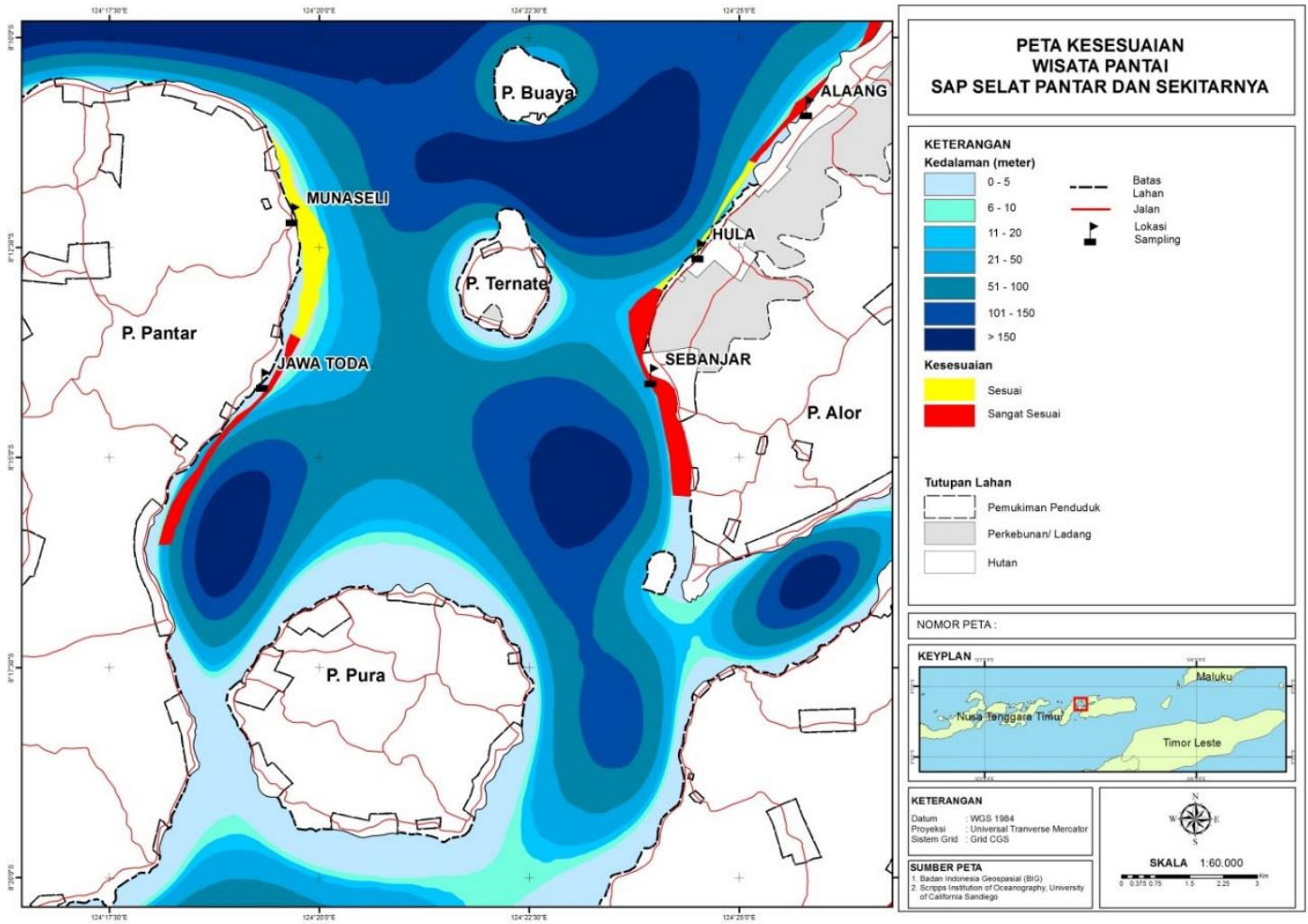

Gambar 1. Peta kesesuaian wisata pantai SAP Selat Pantar

Berdasarkan hasil analisis Indeks Kesesuaian Wisata (IKW), kawasan wisata kategori rekreasi pantai di SAP Selat Pantar termasuk dalam kategori sangat sesuai dan sesuai. Kategori sangat sesuai dengan nilai (IKW: 75 - 100\%) terdapat pada Pantai Sebanjar, Pantai Alaang dan Pantai Munaseli. Sedangkan kategori sesuai (IKW: 50 - <75\%) berada pada Pantai Hula dan Pantai Jawa Toda. Secara keseluruhan 5 titik pengamatan tersebut sangat potensial untuk pengembangan wisata pantai kedepannya. Kondisi ini diperkuat dengan didukungnya nilai setiap parameter kesesuaian dalam kategori sangat sesuai. Parameter tipe pantai tergolong sangat sesuai, lebar pantai sangat sesuai dan kedalaman juga sangat sesuai, parameter ini mempunyai bobot tertinggi dalam kesesuaian wisata pantai. Hasil penelitian ini didukung juga dengan hasil penelitian dari Bakosturnal (2006) Karakteristik lanskap kawasan pantai di Kabupaten Alor sangat unik karena mempunyai tiga karakteristik utama yaitu pantai landai, dataran rendah dan kawasan perbukitan. Ketiganya terintegrasi menjadi satu membentuk kawasan pantai yang menarik.

Hasil ini sangat sesuai dengan kondisi di lapangan dimana pantai-pantai tersebut memiliki hamparan pasir putih yang begitu menawan dan memanjakan mata, desiran ombak dan air lautnya 
yang jernih menjadi daya pikat bagi para wisatawan. keindahan alam tersendiri, dari pantai ini bisa melihat pulau lain didepannya, dengan pasir putih dan air yang jernih menggoda siapa saja untuk berenang kedalamnya. Selain itu pantai-pantai tersebut dijadikan sebagai objek wisata bagi warga pulau seribu moko terutama hari minggu dan libur. Nilai kesesuaian yang tinggi untuk kategori wisata pantai dalam hal ini untuk rekreasi pantai disebabkan oleh tingginya nilai pada setiap parameter yang diukur seperti kedalaman perairan yang tidak lebih dari 3 meter, tipe pantai pasir putih, kecerahan perairan yang tinggi sehingga dasar perairan masih dapat terlihat dengan jelas dengan kasat mata.

\section{Analisa Daya Dukung Kawasan (DDK)}

Menghitung daya dukung kawasan untuk dijadikan sebagai kawasan wisata sangat perlu untuk dilakukan sebab dengan adanya nilai daya dukung kawasan (DDK) suatu wilayah maka dapat diketahui berapa kemampuan kawasan atau wilayah tersebut dapat menampung jumlah maksimal atau optimal dari pengunjung. Hal ini dilakukan untuk mengurangi tekanan akibat dari aktifitas pengunjung di kawasan wisata. Pendapat ini didukung oleh Scheleyer dan Tomalin (2000); Zaakai dan ChadwickFurman (2002) yang mengatakan bahwa salah satu upaya dalam mengurangi tekanan dari aktifitas yang dapat merusak karang atau ekosistem yaitu dengan cara membatasi waktu wisata diving, snorkling dan rekreasi pantai.

Daya dukung KKP Selat Pantar (Tabel 6) dengan mempertimbangkan jumlah potensi ekologis pengunjung, luas area yang termasuk dalam kategori sesuai dan sangat sesuai, dan waktu yang dibutuhkan untuk setiap jenis kegiatan wisata. Pembatasan pengunjung dimaksudkan karena pengembangan wisata tidak bersifat mass tourism, mudah rusak dan ruang untuk pengunjung sangat terbatas (Yulianda 2010) maka diperlukan penentuan daya dukung kawasan. Beberapa hal yang bisa dilakukan untuk mengurangi dampak wisata adalah membatasi trek perjalanan, tempat pemandangan, tempat camp permanen dan penyediaan akomodasi dan membatasi jumlah wisatawan (Pickering dan Hill 2007). Hasil analisis daya dukung kawasan Pantai di SAP Selat Pantar dapat dilihat pada Tabel 6.

Tabel 6 Daya dukung kawasan wisata

\begin{tabular}{cccc}
\hline No & Jenis Kegiatan Ekowisata & Unit Area & DDK \\
\hline 1 & Rekreasi Pantai & $7545 \mathrm{~m}^{2}$ & 322 Orang/hari \\
\hline
\end{tabular}

Sumber : Hasil Olah Data 2016

Berdasarkan Hasil analisis daya dukung kawasan ekowisata pantai SAP Selat Pantar daya dukung kawasan ekowisata rekreasi yaitu 302 orang/hari. Jika dibandingkan dengan jumlah pengunjung yang datang ke pantai SAP berkisar 89 orang/hari. Sehingga dapat disimpulkan bahwa pantai ini dapat menampung seluruh kegiatan wisata yang dilakukan para pengunjung dengan baik tanpa melebihi daya dukung kawasan sehingga pantai ini kelestariannya tetap terjaga.

\section{KESIMPULAN}

Berdasarkan hasil analisis Indeks Kesesuaian Wisata (IKW), kawasan wisata kategori rekreasi pantai di SAP Selat Pantar termasuk dalam kategori sangat sesuai dan sesuai. Kategori sangat sesuai dengan nilai (IKW : 75 - 100\%) terdapat pada kawasan Sebanjar, Alaang, dan Munaseli Sedangkan kategori sesuai (IKW : 50 - <75\%) berada pada kawasan Hula dan Jawa Toda dengan daya dukung kawasan ekowisata pantai kategori rekreasi sebesar 302 (Orang/hari).

\section{DAFTAR PUSTAKA}

Ali D. 2004. Pemanfaatan potensi sumberdaya pantai sebagai obyek wisata dan tingkat kesejahteraan masyarakat sekitar lokasi wisata (studi kasus di Kawasan Wisata Pantai Kartini Jepara) [tesis]. Semarang (ID): Universitas Diponegoro. 
Armos N.H. 2013. Studi Kesesuaian lahan Pantai Wisata Boe Desa Mappakalompo Kecamatan Galesong ditinjau berdasarkan biogeofisik [skripsi]. Makassar (ID): Universitas Hasanuddin.

Dahuri R. 2003. Keanekaragaman Hayati Laut: Aset Pembangunan Berkelanjutan Indonesia. Jakarta (ID): Gramedia Pustaka Utama.

Drumm A, Moore A. 2005. Ecotourism Development - A Manual for Conservation Planners and Managers Volume 1 : An Introduction to Ecotourism Planning. 2nd Edition. Virginia (US): The Nature Conservancy. $96 \mathrm{hlm}$.

[DKP] Dinas Perikanan dan Kelautan. 2015. Rencana Pengelolaan Kawasan Konservasi Perairan Daerah (KKPD) Kabupaten Alor Tahun 2013-2033. Kalabahi (ID): DKP Kabupaten Alor. 172 hlm.

Hazeri G. 2014. Studi kesesuaian Pantai Laguna Desa Merpas Kecamatan Nasal Kabupaten Kaur sebagai daerah pengembangan pariwisata dan konservasi [skripsi]. Bengkulu (ID): Fakulatas Pertanian. Universitas Bengkulu. tidak dipublikasikan.

[KKP] Kementrian Kelautan dan Perikanan. 2015. Kepmen KP Nomor 35/KEPMEN-KP/2015 Tentang Kawasan Konservasi Perairan Selat Pantar dan Laut Sekitarnya di Kabupaten Alor Propinsi Nusa Tenggara Timur. Jakarta (ID): KKP

Pickering CM dan Hill W. 2007. Impact of recreation and tourism on plant biodiversity and vegetation in protected areas in Australia. Journal of Environmental Management. 85(2): 791-800.

Schleyer MH, Tomalin BJ. 2000. Damage on South African coral Reefs and an assessment of their sustainable diving capacity using a fisheries approach. Bulletin of Marine Science. 67(3):10251042.

Yulianda F. 2007. Ekowisata Bahari sebagai alternative Pemanfaatan Sumberdaya Pesisir Berbasis Konservasi. Seminar Sains Departemen Manajemen Sumberdaya Perairan. Bogor (ID): Institut Pertanian Bogor.

Yulianda F, Fahrudin A, Hutabarat, Armin A, Sri H, Kusharjani, Sang KH. 2010. Pengelolaan Pesisir dan Laut Secara Terpadu. Book 3. Bogor (ID): Pusdiklat Kehutanan-Departemen Kehutanan RISECEM- Korea International Coorporation Agency.

Zaakai DNE, Chadwick-Furman C. 2002. Impacts of intensive recreational diving on reef corals at Eiliat, Northern Red Sea. J. Biol. Conserv. 105(4):179-187. 